\title{
Discussion: Choose your future: a feminist perspective on Construction 4.0 as techno-utopia or digital dystopia
}

Jenni Barrett MA (Hons), MSt, PhD

Senior Lecturer, Faculty of Culture and Creative Industries, University of Central Lancashire, Preston, UK (Orcid:0000-0002-6795-1615)

\section{Contribution by David Cunningham}

In her research paper 'Choose your future: a feminist perspective on Construction 4.0 as techno-utopia or digital dystopia', Dr Jenni Barrett (2020: p. 153) asserts without evidence that Construction 4.0 is 'gendered' and states that the 'currently gendered idea of Construction 4.0 could exacerbate current gender divisions and inequalities that currently blight the construction industry'.

This unsupported premise frames the argument that follows, which consists of a parade of different literary titles dealing with utopias and dystopias.

Dr Barrett (2020: p. 156) includes a reference to the 1996 film Trainspotting, recalling the moment

... when Renton instructed society to guard against blind consumption of new technology without attention to personal and social needs in the 1996 film Trainspotting. (Hodge et al., 1997)

Dr Barrett possibly intends to suggest the following monologue (Monologuedb, 2021):

\begin{abstract}
Choose a job. Choose a career. Choose a family. Choose a $\mathrm{f}^{* * * i n g}$ big television. Choose washing machines, cars, compact disc players and electrical tin openers. Choose good health, low cholesterol, and dental insurance. Choose fixed interest mortgage repayments. Choose a starter home. Choose your friends. Choose leisurewear and matching luggage. Choose your future. Choose life... But why would I want to do a thing like that? I chose not to choose life. I chose something else. And the reasons? There are no reasons. Who needs reasons when you've got heroin?
\end{abstract}

'Who needs reasons when you've got heroin?' is not a viewpoint likely to be shared by many members and fellows of the Institution of Civil Engineers

Dr Barrett (2020: p. 156) concludes with a 'call to arms':

\footnotetext{
May civil engineers now subvert the genre and intersect gender inclusivity across all aspects of future research, innovation and strategy in relation to Construction 4.0, so that this utopia might actually be realised and not dispatched to the long list of the construction industry's dystopian disappointments.
}

David Cunningham MSc, BSc (Eng), FICE, CEng Formerly DAC \& Associates Project Management Pte. Ltd, Singapore

If Dr Barrett wishes to encourage more women into civil engineering, she might draw attention to the significant successes in the use of Construction 4.0 tools and technologies, in areas ranging from improvements in project controls by way of introduction of a common data environment, to the reconstruction of Notre Dame Cathedral supported by a comprehensive 'digital twin' virtual model of the cathedral developed through a combination of virtual reality, three-dimensional modelling and cloud computing technologies (Platt, 2021).

\section{Author's reply}

The author agrees with the suggestion that the range of tools and technologies developed as part of Construction 4.0 in recent years provide exciting and attractive opportunities for those wishing to enter the civil engineering profession. However, the author questions whether these opportunities will be available for everyone. There is a significant body of historical and contemporary evidence that both 'construction' and 'technology' are gendered terms and practices. Examples of this supporting evidence are cited in the paper by way of numerous sources, such as the papers by Fowler and Wilson (2004), Wajcman (2010) and Herman (2015) among many others.

The author offers an array of literary sources as a reflection of this cultural reality. These texts provide an important cultural resource, context and narrative parallel by which to theorise the social reality, a common approach in sociological inquiry. When the fictional narrative is described in juxtaposition with the academic and government literature, it highlights the futility of attempting to achieve gender equity by encouraging women into civil engineering through celebration of its technologies, without attention to the endemic social or cultural context.

The author agrees that the methodological approach is not typical of research in the civil engineering field. The atypical and interpretivist approach is both valid and important, so that alternative viewpoints can be understood and appreciated. In this case, the approach has been particularly useful, as it has allowed a new viewpoint to be communicated, which may, or may not, be at odds with the views that are traditionally held within the industry, yet resonate with its poor performance in relation to gender representation and pay gap data. 
The quote from the 1996 film Trainspotting was used as a contribution to this interpretivist narrative. Unfortunately, the contributor assumes a somewhat different quote from the one that is being referred to in the paper, one that is not alluded to or discussed at any point. Instead, the previous lines from the film are those being discussed. They ask us to 'choose our future'. The author asks that society choose a diverse and inclusive future, rather than accepting a gendered inevitability.

As a leader of the Women in BIM international network, the author is all too familiar with the barriers that face women in digital construction careers. One of the key issues here is that the 'significant successes in the use of Construction 4.0 tools and technologies' that the contributor suggests might encourage them are produced and implemented disproportionately by men, including those suggested. This can indicate to women that they are less likely to be able to engage in these opportunities, and it can have the opposite effect, discouraging them from joining or staying in the profession, thus reinforcing the problem. The paper challenges this story that new technologies can bring a new utopia for the industry, offering an alternative but vital viewpoint to the dystopian technocracy.

\section{REFERENCES}

Barrett J (2020) Choose your future: a feminist perspective on Construction 4.0 as techno-utopia or digital dystopia. Proceedings of the Institution of Civil Engineers - Management, Procurement and Law 173(4): 153-157, https://doi.org/10.1680/jmapl.20.00003.

Fowler B and Wilson F (2004) Women architects and their discontents. Sociology 38(1): 101-119, https://doi.org/10.1177/0038038504039363. Herman C (2015) Rebooting and rerouting: women's articulations of frayed careers in science, engineering and technology. Gender, Work \& Organization 22(4): 324-338, https://doi.org/10.1111/gwao.12088. Hodge J, Boyle D and Welsh I (1997) Trainspotting. Miramax Films, London, UK.

Monologuedb (2021) See http://www.monologuedb.com/dramatic-malemonologues/trainspotting-rent-boy-renton/ (accessed 13/05/2021).

Platt KH (2021) Notre Dame rescue is buttressed by digital wizardry. Financial Times, 16 February.

Wajcman J (2010) Feminist theories of technology. Cambridge Journal of Economics 34(1): 143-152, https://doi.org/10.1093/cje/ben057.

\section{How can you contribute?}

To discuss this paper, please email up to 500 words to the editor at journals@ice.org.uk. Your contribution will be forwarded to the author(s) for a reply and, if considered appropriate by the editorial board, it will be published as discussion in a future issue of the journal.

Proceedings journals rely entirely on contributions from the civil engineering profession (and allied disciplines). Information about how to submit your paper online is available at www.icevirtuallibrary.com/page/authors, where you will also find detailed author guidelines. 